\title{
The Consumption Preferences of Milk and Dairy Products of Undergraduate Students
}

\author{
Mustafa Mortas and Fehmi Yazıcı \\ Department of Food Engineering, Ondokuz Mayıs University, Samsun 55139, Turkey
}

Received: October 8, 2011 / Published: January 20, 2012.

\begin{abstract}
Human has different stages in their life as from babyhood to adult. The healthy and balanced diet preferences of people play an important role in each human life parts. Especially milk and dairy products are necessary for human health because of their nutrition value and body functions. One of the parts of people life is university life. Starting university is a turning point in terms of eating habits, since food choices responsibility of university students increases in this period. According to the researches, increasing availability of fast foods, changes in living arrangements, life experiences, expectations, preferences and beliefs related with food selections are most common reasons regarding dietary choices in this young adults group. University students had drinking milk habits in primary school but most of them lose their habits during university life. The students' first preferences were cheese and then yogurt and finally milk. A very little part of university students consume milk and dairy products regularly. The consumption habits and milk and dairy product catering of university students were examined. The consumption preferences of milk and dairy products of the students in different Universities are reviewed in this review.
\end{abstract}

Key words: Milk, dairy products, consumption preferences, undergraduate students.

\section{Introduction}

Starting university can change something in students' life. One of the changes is that eating habits may affect their life and health. University students can have some new consumption preferences like consuming fast food, alcoholic beverages at the same time they can lose some consumption preferences as consuming milk and dairy products. Determination of college students' milk and milk products catering by means of questionnaires is very important because of the fact that providing awareness of consumption. That's why it should be examined from benefits of milk to different results of questionnaires related to milk and dairy product catering of university students.

People's life, achievements and productivities are related to their healthy and balanced diet. Nutrition is defined as keeping health and quality life by taking

\footnotetext{
Corresponding author: Mustafa Mortas, researcher, research field: milk technology. E-mail: mustafa.mortas@omu.edu.tr.
}

healthy and balanced diet. A good eating habit is related to taking different compounds from animal and plant based foods [1,2].

Human health is influenced by different factors as individual's lifestyle and genetic factors [3]. Nutritional intake is one of the important factors affecting on human health. It has been documented importance of healthy eating against to chronic disease [4].

Consumers make their food purchasing decisions according to price, health, taste and convenience [5-9]. However, food selection is depending on some complex internal and external factors. The external factors as environmental, demographic and socioeconomic can be determined easily [10]. Nevertheless, some internal factors like values, concerns, beliefs regarding foods can be measured difficultly [11]. Consuming milk and milk products depends on people's eating habits, ages, income and other important factors.

On the other hand, milk has a different place among 
foods. Milk has approximately 85 compounds (organic acid, hormone, minerals, vitamins etc.) $[1,2]$. It is important because it has adequate amount of protein, lactose, fat, vitamin and minerals for the body. It is not only having high nutritional value but also regulate body functions. Furthermore, milk plays an important role for development of bones and teeth [12]. Another point to be kept in mind is that milk is a good source of energy, providing about $650 \mathrm{kcal}$ energy/1,000 g milk [13].

Daily milk requirement changes for humans. Milk requirement for baby is $700 \mathrm{~g}$, for children $400 \mathrm{~g}$, for young $350 \mathrm{~g}$, for adults $250 \mathrm{~g}$, for pregnant $500 \mathrm{~g}$ and finally for old people $350 \mathrm{~g}[14,15]$.

Annual milk consumption per person is $30 \mathrm{~kg}$ in Turkey, $95 \mathrm{~kg}$ in European Union, $95.3 \mathrm{~kg}$ in United States of America, $94.4 \mathrm{~kg}$ in Russia, $108.4 \mathrm{~kg}$ in Australia. In Turkey and USA, butter consumption per person is $1.3 \mathrm{~kg} /$ year. It is $4.5 \mathrm{~kg}$ in EU, $3.5 \mathrm{~kg}$ in Russia, and $3.2 \mathrm{~kg}$ in Australia. Annual cheese consumption per person is $12.5 \mathrm{~kg}$ in Turkey, $17.5 \mathrm{~kg}$ in EU, $13.1 \mathrm{~kg}$ in USA, $8.8 \mathrm{~kg}$ in Australia, and $3.6 \mathrm{~kg}$ in Russia [16, 17].

Recommended calcium intake for young adult men and women (19 to 30 years old) is $1.00 \mathrm{mg} /$ day [18], however this amount is frequently not met [19]. Milk is the most important food in terms of contributing the bone density of people from childhood to adulthood on the way during each stage of life [20-25].

\section{University Life and Eating Habits}

Health of individuals in the long term can be affected by dietary habits acquired in early life [26]. There are some evidences that lifestyle and diet in youth may have long-term health implications [27]. Starting university is a turning point in terms of eating habits, since food choices responsibility of university students increases in this period [28].

Another point kept in mind is that this group is callow with respect to food shopping and preparation of meal [29]. Furthermore, increasing availability of fast foods [30], changes in living arrangements [31], life experiences, expectations, preferences and beliefs related with food selections $[8,32]$ are most common reasons regarding dietary choices in this young adults group.

University students are a transition group between childhood and adult. Their eating habits may change because of leaving their family. So their eating preferences can change. This period is important for their future from the point of view of how to change their eating habits [33].

\section{Undergraduate University Students’ Milk and Dairy Consumptions}

There are a lot of studies related with consumption of milk and dairy products for students and other people [15, 34-38].

It is stated that cheese is the most consumed dairy product in a study on university students in Konya. It was concluded that university students did not have enough information about nutritional value of milk and did not consume milk and milk products adequately [34].

In a survey carried out on university student in Istanbul, $11 \%$ of students consumed milk at breakfast. A part of students (18.75\%) consumed 0.5 Liter of milk during a day. However, it is stated that $29 \%$ of students did not consume any milk [39].

In another study, students' first preferences were cheese and then yogurt and finally milk [40].

Tarakcı et al. [41] stated that milk consumption of undergraduate students in Yuzuncu Y1l University was $3.7 \mathrm{~kg} / \mathrm{month}$ per student. The average milk consumption was $100 \mathrm{~g}$, only one third of daily requirement.

Another study examined the consumption-habits of undergraduate students (362 students) of Yuzuncu Y1l University. The most consumed dairy product was white cheese (524 g/week). The second most consumed cheese type was Otlu (Herby) cheese. Full fat yoghurts were mostly preferred among the students. $98 \%$ of the university students consumed Ayran [37]. 
Mazıcioglu and Ozturk [33] stated that $7.8 \%$ of students in Erciyes University consumed milk in their breakfast and $9.3 \%$ of them consumed regularly.

In a questionnaire carried out on 113 students of the Engineering Faculty of Celal Bayar University, 63.7\% of students consumed milk; $79.1 \%$ of them had this habit at primary school. Their families were the major factor to start to drink milk. Furthermore, $56 \%$ of students stated that they consume less milk than that of their childhood period [42].

Y1lmaz and Ozkan [43] have searched the eating habits of Balıkesir University students. It was stated that only $5.1 \%$ of students consumed milk compared to $65.7 \%$ of tea. Furthermore, $4 \%$ of the students consumed ayran, $22.3 \%$ of them yogurt and $76 \%$ of them cheese.

Ozen et al. [44] declared that $28 \%$ of the university students in Istanbul consume fizzy drinks every day but $67.7 \%$ of them drink milk generally.

In a study, it is stated that $13.8 \%$ of the Physical Education students in Ankara drink milk in their breakfast and the other students drink fruit juices or tea. $28.6 \%$ of male and $38.1 \%$ of female students consume cheese at breakfast time. Another point to be kept in mind is that the knowledge of students about milk and milk products was found in limited levels [45].

In another study, the situations of animal products consumption and consumer preferences among intern students at the Ankara University Faculty of Veterinary Medicine were examined. This study was carried out among 122 students in the education period of 2006-2007. According to result of the questionnaire, $67.1 \%$ of the students spent less than 200 TL (108 \$) for their monthly food consumption. On the other hand, $8.2 \%$ of the students never consumed milk as a drink. Another point is that milk and meat were purchased from supermarket by $95.1 \%$ and $83.7 \%$ of students [46].

Cetinkaya [47] have conducted a study related with consumption habits of milk and milk products among the students in Kafkas University. For this purpose, 750 university students having education in a different department of Kafkas University were used as a material. $33 \%$ of the students had milk consumption but $67 \%$ of them never drank milk over the study period. According to results of the study, the consumption ratios of yoghurt, cheese, butter, milk powder, and milk with fruit and yoghurt with fruit were $34 \%, 49 \%, 12 \%, 1 \%$, and $2 \%$, respectively. It was stated that the majority of the students: (1) did not have the habit of regularly drinking milk, (2) mostly consumed cheese and yoghurt instead, and (3) had a very limited knowledge of drinking milk and milk products.

A study was carried out to determine case of probiotic product consumption of randomly selected university students (with 1,000 students). It was found that similarly half of students (58.4\%) did not know anything about probiotic products and a big part of students (74\%) did not know microorganisms in probiotic products. However, it is stated that $25 \%$ of students consumed and incidence of probiotic products consumption was higher at girls [48].

\section{Conclusion}

College students are a transition group between childhood and adult. Their eating habits may change in this period by different factors. This changing may affect their life and health. Drinking milk habit coming from childhood should continue in this period. But the college students are not aware of the importance of milk consumption and milk products. There are a lot of questionnaires related with consuming milk and milk products. If the studies in this area increase, we can have statistical data about university students' knowledge of milk and dairy products. Furthermore, their habits of consuming milk and milk products may be better.

\section{References}

[1] M. Demirci, S. Kurultay, O. Oksuz, A research on determination of the drinking milk consuming habits and the factors affecting these habits in Tekirdag Province, 
Symposium on Drinking Milk, Tekirdag, 1998, pp. 149-157. (in Turkish)

[2] A. Yetismeyen, Milk Technology, Course Book, 1420, Faculty of Agriculture, Ankara University, Ankara, 410 (1995) 230. (in Turkish)

[3] S. Yoshii, S. Kamimotono, S. Sawai, M.B. Matsushita, F. Tanaka, D. Rujkorakam, Cross-sectional survey on the relationship between dairy product intake and bone density among adult women and high school students, Nutrition Research 27 (2007) 618-624.

[4] W.C. Willett, Diet and health: What should we eat, Science 264 (1994) 532-537.

[5] M.A. Bock, M. Read, C. Bruhn, G. Auld, K. Gabel, G. Lauritzen, et al., Gender and ethnic differences in factors that influence food choice, Journal of Consumer Studies \& Home Economics 22 (1998) 25-37.

[6] I.R. Contento, J.L. Michela, C.J. Goldberg, Food choice among adolescents: Population segmentation by movitations, Journal of Nutrition Education 20 (1988) 289-298.

[7] L.W. Falk, C.A. Bisogni, J. Sobal, Food choice processes of older adults, Journal of Nutrition Education 28 (1996) 257-265.

[8] T. Furst, M. Connors, C.A. Bisogni, J. Sobal, L.W. Falk, Food choice: A conceptual model of the process, Appetite 26 (1996) 247-265.

[9] L.H. Rappoport, G.R. Peters, L. Huff-Corzine, R.G. Downey, Reasons for eating: An exploratory cognitive analysis, Ecology of Food and Nutrition 28 (1992) 171-189.

[10] M. Abernethy, M.T. Kuczmarski, Food intake and food related attitudes of older women: Implications for nutrition education, Journal of Nutrition Education 26 (1994) 3-9.

[11] L.S. Sims, Further thoughts on research perspectives in nutrition education, Journal of the American Dietetic Association 87 (9) (1987) 10-18.

[12] T. Ozcan, F. Erbil, E. Kurdal, The importance of milk of human nutrition, in: Drinking Milk Symposium, Tekirdag, 1998, pp. 31-41. (in Turkish)

[13] M. Metin, Milk Technology, Ege University Publishing, Izmir, 1999, p. 793. (in Turkish)

[14] I. Rasenthal, Milk and Dairy Product, Properties and Processing, VCH, Cambridge, Basel, New York, 1991.

[15] A. Ayar, H. Demirulus, The determination of consumption patterns of milk and milk products of school age youth, Journal of Food 25 (2000) 371-376. (in Turkish)

[16] Anonymous, Dairy Breeding, Current Situation of Our Country, Problems and Suggestions, Turkey Union of Agricultural Chambers Reports [online], 2005, http://www.tzob.org.tr. (in Turkish)

[17] Anonymous, Milk and Milk Products Common Market
Organizations, Working Group Report [online], 2005, SETBIR Publications, http://www.setbir.org.tr/media/webopdsut.zip.

[18] A.A. Yates, S.A. Schlicker, C.W. Suitor, Dietary references intakes: The new basis for recommendations for calcium and related nutrients, B vitamins and choline, Journal of the American Dietetic Asssociation 98 (1998) 699-706.

[19] L.H. Eck, C. Hackett-Renner, Calcium intake in youth: Sex, age and racial differences in NHANES II, Preventive Medicine 21 (1992) 473-482.

[20] Y. Toba, Y. Takada, J. Yamamura, M. Tanaka, Y. Matsuoka, H. Kawakami, et al., Milk basic protein: A novel protective function of milk against osteoporosis, Bone 27 (2000) 403-408.

[21] J. Yamamura, S. Aoe, Y. Toba, M. Motouri, H. Kawakami, M. Kumegawa, et al., Milk basic protein (MBP) increases radial bone mineral density in healthy adult women, Biosci Biotechnol Biochem. 66 (2002) 702-704.

[22] W.T. Lee, S.S. Leung, S.S. Lui, J. Lau, Relationship between long-term calcium intake and bone mineral content of children aged from birth to 5 years, British Journal of Nutrition 70 (1993) 235-248.

[23] M. Lunt, P. Masaryk, C. Scheidt-Nave, J. Nijs, G. Poor, H. Pols, et al., The effects of lifestyle, dietary dairy intake and diabetes on bone density and vertebral deformity prevalence: The EVOS study, Osteoporos International 12 (2001) 688-698.

[24] E.M. Lau, J. Woo, V. Lam, A. Hong, Milk supplementation of the diet of postmenopausal Chinese women on a low calcium intake retards bone loss, Journal of Bone and Mineral Research 16 (2001) 1704-1709.

[25] X.Q. Du, H. Greenfield, D.R. Fraser, K.Y. Ge, Z.H. Liu, W. He, Milk consumption and bone mineral content in Chinese adolescent girls, Bone 30 (2002) 521-528.

[26] A. Johansen, S. Rasmussen, M. Madsen, Health behavior among adolescents in Denmark: Influence of school class and individual risk factors, Scandinavian Journal of Public Health 34 (6) (2006) 32-40.

[27] C.C. Georgiou, N.M. Betts, S.L. Hoerr, K. Keim, P.K. Peters, B. Stewart, et al., Among young adults, college students and graduates practiced more healthful habits and made more healthful food choices than did nonstudents, Journal of the American Dietetic Asssociation 97 (7) (1997) 754-759.

[28] I.C. Baric, Z. Satalic, Z. Lukesic, Nutritive value of meals, dietary habits and nutritive status in Croatian university students according to gender, International Journal of Food Sciences and Nutrition 54 (6) (2003) 473-484.

[29] N. Bull, Studies of the dietary habits, food consumption and nutrient intakes of adolescents and young adults, World Reviews in Nutrition and Dietetics 57 (1998) 24-74. 
[30] T.A. Nicklas, T. Baranowski, K.W. Cullen, G. Berenson, Eating patterns, dietary quality and obesity, Journal of the American College of Nutrition 20 (6) (2001) 599-608.

[31] P.B. Brevard, C.D. Ricketts, Residence of college students affects dietary intake, physical activity, and serum lipid levels, Journal of the American Dietetic Association 96 (1) (1996) 35-38.

[32] H. Pei-Lin, Factors influencing students' decisions to choose healthy or unhealthy snacks at the University of Newcastle, Australia, Journal of Nursing Research 12 (2) (2004) 83-91.

[33] M.M. Mazıcıoğlu, A. Ozturk, Dietary habits and influencing factors in university students at 3rd and 4th grades, Erciyes Medical Journal 25 (4) (2003) 172-178. (in Turkish)

[34] S. Hasipek, N. Aktas, M.S. Surucuoglu, N. Akın, Milk and dairy products consumption frequency and factors affecting this of students at the Faculty of Agriculture in Selcuk University, Konya, Food 13 (2) (1988) 99-106. (in Turkish)

[35] G. Ersoy, Preschool 3-6 age group children and their milk and milk derivatives consumption, Food 15 (6) (1990) 349-354. (in Turkish)

[36] H. Durmaz, E. Sağun, Z. Tarakcı, Drinking milk consumption habits of vocational school students, Yuzuncu Y1l University, Faculty of Veterinary Journal 13 (1-2) (2002) 69-73. (in Turkish)

[37] S. Selcuk, Z. Tarakc1, K. Sahin, H. Coskun, Dairy products consumption habits of undergraduate students of Yuzuncu Y1l University, Faculty of Agriculture, Journal of Agricultural Science 13 (1) (2003) 23-31. (in Turkish)

[38] O. Simsek, C. Cetin, B. Bilgin, A research on determination of the drinking milk consumption habits and the factors affecting these habits in Istanbul province, Tekirdag University, Journal of Tekirdag Agricultural Faculty 2 (19) (2005) 23-35. (in Turkish)

[39] I. Y1lmaz, M. Demirci, Dietary habits of university students, Dünya Gıda (2001) 83-86. (in Turkish)

[40] S. Hasipek, N. Kaleli (Sevenay), A research on consumption frequency of milk and milk products by male and female students living in dormitory of Ankara university faculty of agriculture, Faculty of Agriculture, Ankara University, Journal of Agricultural Science 8 (3) (2002) 204-207. (in Turkish)

[41] Z. Tarakcı, S. Selcuk, K. Sahin, H. Coskun, A study on the habits of fluid milk consumption of the students at the University, Yuzuncu Y1l University, Faculty of Agriculture, Journal of Agricultural Science 13 (1) (2002) 15-21. (in Turkish)

[42] N. Karagozlu, C. Karagozlu, S. Karaca, S. Eren, A research on the consume habits of dairy products and nutritional consiousness of university students: An example of Celal Bayar University, Engineering Faculty, Celal Bayar University Journal of Science 1 (2) (2005) 101-108. (in Turkish)

[43] E. Y1lmaz, S. Ozkan, Investigation of nutritional habits in university students, Firat Journal of Health Service, Elazig 2 (2007) 6. (in Turkish)

[44] A.O. Ozen, M. Berber, H.E. Sarıcoban, B. Buyukgebiz, Determination of nutritional attitudes and behaviors of college students studying in Istanbul [online], 2007, http//www.millipediatri.org.tr/bildiriler/pp-058.htm. (in Turkish)

[45] T. Sevindi, G. Y1lmaz, S. Ibis, B. Y1lmaz, The evaluation of the nutrition habits among the students of physical education and sport high school department of Gazi University, TSA, 2007. (in Turkish)

[46] Y. Cevger, Y. Aral, P. Demir, S. Sarızkan, The situation of animal products consumption and consumer preferences among intern students at the Ankara University Faculty of Veterinary Medicine, Ankara University, Journal of Veterinary Faculty 55 (2008) 189-194. (in Turkish)

[47] A. Çetinkaya, A survey of the consumption habits of milk and milk products among the students in Kafkas University, Ataturk University, Journal of Veterinary Sciences 5 (2) (2010) 73-84. (in Turkish)

[48] M. Aydın, I. Acıkgoz, B. Simsek, Determination of probiotic product consumption and probiotic concept knowledge level in students of Isparta Süleyman Demirel University, Electronic Journal of Food Technologies 5 (2) (2010) 1-6. (in Turkish) 